\section{CRITICAL THINKING AS INSTITUTIONALISED PRACTICE: EAST AND WEST COMPARED ${ }^{1}$}

\section{Erik Ringmar $^{2}$}

East Asian societies are often said to be 'conformist' and conformism is said to be a bad thing. Conformism means that people defer to the authority of others and fail to exercise their own judgement. The result is, allegedly, a stunted personal growth, and for societies as a whole, a stunted economic growth. For example: the Japanese economy is sometimes said to be doing badly because its schools fail to teach creativity and independence of thought. ${ }^{3}$ Similarly, Thailand is said to face serious challenges moving into an economic niche which requires people not only to have knowledge, but to manipulate it in unconventional ways (Asian Development Bank, 2000; World Bank, 2000). The remedy in the case of these two countries, and in the case of others throughout East Asia, is supposed to be 'critical thinking.'

\footnotetext{
I am grateful to Soraj Hongladarom, Chun Lin, Ornan Rotem, and an anonymous reviewer for comments on a previous version of this article.

${ }^{2}$ Dept of Government, London School of Economics.

${ }^{3}$ 'It is necessary for 'Japan to add "genuine creation" to its copy-and-improve talents.'

Naito Yoshiyuki, president of the Tokyo Institute of Technology. (Asia Week, 1999)
}

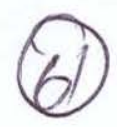

The classical statement of this position is that of the English $19^{\text {th }}$ century philosopher John Stuart Mill (Mill, 1859/ 1985: 119-40).As Mill saw it, it was the individualism of the West that guaranteed its rapid development.In the West, people made their own choices rather than relying on social custom to make decisions for them.By exercising their independent judgement, Westerners develop to their full human potential; they come to have character, originality, even eccentricity. In the West, people are encouraged to think for themselves, and as a result, public debates are always full of a large number of divergent points of view. While there is no $a$ priori way of saying which of these opinions that is correct, the wide range of views guarantees that all opinions will get an airing. Since the future is unknown, safety is to be found in numbers; critical thinking and free debate are the best guarantees of continuous social progress (Mill, 1859/1985: 79-81).

Turning to East Asia, Mill found neither critical thought nor free debate. On the contrary, here 'the despotism of custom is everywhere the standing hindrance to human advancement' (Mill, 1859/1985: 136-37). East Asians defer to the judgement of others, individuality is suppressed, and neither character nor originality are allowed to form. The minds of East Asians are, like the feet of Chinese women, maimed by compression (Cf. Mill, 1859/1985: 135). As a result, East Asia has became stationary and remained so for thousands of years; this part of the world can consequently not, properly speaking, be said to have a history. Thus while East Asian societies created the most magnificent palaces and temples back in the days 
when the Europeans still were living in forests, they were now colonised by the descendants of these very same forestdwellers.And, as Mill concluded, 'if they are ever to be further improved, it must be by foreigners.' 'A people, it appears, may be progressive for a certain length of time, and then stop: when does it stop? When it ceases to possess individuality' (Mill, 1859/1985: 13637).

Mill's view of East Asia is still common enough in the West and it lives on as a condescending, basically racist, stereotype. East Asians may work hard, the argument goes, but they are fundamentally unimaginative; they know how to copy things and how to improve them, but they are not able to create new things from scratch (Baba \& Imai, 1992). While East Asians function efficiently in groups, they are helpless alone, and while they perform outstandingly in an industrial economy, they do badly in a world where money increasingly is made from the creative manipulation of symbols (Maruyama, 1997: 287-302; Hofstede, 1980: 148-75).

Yet there is obviously something wrong with this stereotype. If nothing else, Mill was certainly incorrect about East Asia remaining 'stagnant.' In stark contrast to his predictions, the region has changed dramatically over the course of the last century, and during the last thirty years, economic growth has been very impressive indeed, averaging between 5 and 10 percent per year. The comparison with other non-European societies is particularly striking. Outside of the West, only East Asia has managed to become what usually is referred to as a 'modern' country.
The question remains, however, what exactly that was wrong with Mill's view. The aim of this article is to answer this question. The argument made and defended here is, first, that East Asia is far less conformist and more creative than Westerners tend to think, and, secondly, that the role that Westerners attach to individuality is vastly exaggerated. As far as East Asia is concerned, there has always been more place for critical thinking than Mill and other Europeans have acknowledged. And as far as the West is concerned, individuals and their character have never been as important as they themselves have tended to believe.Critical thinking is in the end a social, not an individual, achievement. The creative potential of society is a matter of institutionalised practices, and it has next to nothing to do with the contributions of a few eccentric individuals.

\section{Critical Thinking as Reflection}

Critical thinking could certainly mean a number of different things. Focusing on the 'critical' part, critical thought could be understood as 'negative thought,' thought that always is against and never is able to see the positive side of an issue. As such it is easily presented as destructive both to individuals and to societies. It may, for example, be far better for the soul of an individual to think positively than to think negatively. 'Pessimism leads to weakness,' while 'optimism leads to power. ${ }^{4}$ Similarly,

\footnotetext{
${ }^{4}$ Compare the discussion of "The Religion of Healthy-Mindedness," in James, 1902/ $1985: 107$. The quote refers to the teaching of Christian science.
} 
as far as the body politic is concerned, too much negativism may cause dissension and strife and thus undermine the social order. This, at least, is always how critical thinking will be portrayed by political or religious authorities bent on restricting or banning it.

More generously interpreted, however, critical thinking is a constructive force and as such a precondition both for individual and collective well-being. To think critically is to refuse to take things at face value; it is to reserve judgement until one has had a chance to make up one's own mind. That is, a verdict is postponed until a standard has been established by which a particular issue, event, or situation can be properly judged. People who exercise their critical faculties in this way are not easily taken in, they are street-smart and wise.

What street-smart and wise people have in common, in other words, is the ability to distance themselves from the situation at hand and to judge it in terms of previous experiences. This is also the literal meaning of the word 'critique.' Krinein, in Greek, means 'to judge,' and krisis means 'a judgement'(Dictionnaire historique de la langue française, 1993; Koselleck, 1988: 103-4). Both terms were originally used in a medical context. When confronting a patient, the doctor would draw on his training and professional experience in order to provide a diagnosis of the illness. To be 'critically ill' is, etymologically speaking, to be at a stage in an illness where such diagnoses are particularly easy to make. Or, changing the metaphor, perhaps the position of the doctor could be compared to that of a spectator in a the- atre (Arendt, 1977: 92-94).5 While the actor, caught in his or her character, never understands the full import of what he or she is doing, the spectator, seeing the performance from a distance, is a much better judge of the unfolding of events. What doctors and theatre critics do, in short, is to reflect on whatever they have in front of them, and reflection is also at the core of what is meant by critical thought.

Metaphorically speaking, to reflect is to 'go back in thought,' to 'consult with oneself'; it is to throw out an idea and let the mind try to retrieve it (Dictionnaire historique de la langue fran?aise; Consise Oxford Dictionary). Thus understood, reflection is an aspect of thinking, but to say that someone 'reflects on a matter' gives a particular emphasis to the technical aspects of the process of cognition. To reflect is not just to think, but rather to put in motion what could be called the 'optics' of cognition. Just as reflections of light, reflections of the mind require a certain set-up. You need distance, a focus, and an appropriate point of view.

The most important requirement for a process of reflection to begin is no doubt distance. It is only at a distance that one can see what things really look like. Distance is often difficult to achieve, however, especially if the object of reflection is one's own person or the society in which a person lives. Since we

\footnotetext{
'This is also how the word 'critique' was used in the German philosophical tradition. Compare, for example, Immanuel Kant's Critique of Pure Reason. For a recent discussion, see Halberstam, 2000: 71-112.
} 
never can leave ourselves, we can never see ourselves from the outside, and while we physically can remove ourselves from our societies, this in itself does not provide us with a better point of view as long as we do not also shed our society's preconceptions.

In order to achieve distance, we must look for ways of extending ourselves, of making ourselves into objects available for observation. Here technical solutions often provide the answer perhaps it is possible to talk about the use of different 'technologies of reflection.' ${ }^{6}$ The most obvious example of such a technology is a mirror (Miller, 1998; Gregory, 1998). The mirror presents an external image to which a person can relate as he or she would to any other object in the world. We are here, but also there on the wall in front of us, and the distance between the two versions of ourselves is what makes reflection possible. The mirror reflects our image, but it also allows us to reflect on it.

Other examples of technologies of reflection are language and writing (Goody, 1986 Goody \& Watt, 1963: 30445). When either spoken or written down, internal thoughts are transformed into external objects to which others, or we ourselves, can refer. In this way, language and writing create distance and distance allows reflection to begin. In addition, writing will vastly increase the reflective potential of a society since it allows people to communicate not only

'Or what McLuhan calls 'media.' McLuhan, 1964/1998: 7-21. with those immediately present, but also with far wider, virtual or imagined, communities. Amazingly, writing also makes it possible for us to communicate with the dead or with the not yet born. In today's world, this process of collective reflection is enormously speeded up with the help of newspapers and other mass media, computers and the internet.

Since technologies of reflection vary widely in their effects, the presence or absence of a particular technology will make a huge difference to the reflective capability of a society. For purely technical reasons, some societies are more reflective than others. This makes it possible to compare societies and to rank them according to their reflective potential. Note, however, that this is not a comment on the quality of the thought produced. In order to think well, you have to arrive at correct, interesting, or morally praise-worthy results, but in order to reflect well, all you need is access to a particular set of technological gadgetry. Although thought hardly can be said to have made much progress from the time of Socrates or Confucius until today, reflection decidedly has. While modern societies may be less thoughtful than pre-modern, they are vastly more reflective.

\section{Individuals and Institutions}

The Western view puts the responsibility for critical thought on the shoulders of individuals. It is accordingly up to individuals to exercise their reflective judgement, and if they fail in this duty, social progress will be jeopardised. What thus far has been said about technologies of reflection will, however, cast a first set of doubts on this conclusion. 
Technological factors matter crucially for reflection, but technological factors are also located far beyond individual control. Mirrors, language and writing either exist in a society or they do not, and if they do not, they are not the kinds of things an individual can make up on his or her own. Here the qualities of individuals - whether they are 'individualistic,' 'creative' and 'critical' or not — will make little or no difference.

In fact, the individualistic assumptions were always exceedingly heroic. The idea was that individuals would form their independent judgement and to stand up for it even in the face of the inattention, or opposition, from society at large. This is a romantic view, common in Hollywood movies, of the single individual who fights against injustice and who, against all odds, is vindicated. What happens in Hollywood movies, however, rarely happens in real life. What never is explained is how this independence is supposed to be achieved. It is not clear how individuals can form their own judgement apart from, or in opposition to, the society into which they have been socialised.

Mill himself worried about this question (Mill, 1859/1985: 131-32). He feared that individuality would be repressed in a modern society ruled by 'collective mediocrity' and 'public opinion.' All political changes of the age, he argued, repress individuality since they 'raise the low and lower the high,' and education, communications, commerce and manufactures all contribute to the same end. In fact, this is precisely why Mill turned to a discussion of East Asia. His greatest fear was that Europe would fail to see the danger and thus end up as 'an- other China' (Mill, 1859/1985: 138).

Yet the point surely applies to all kinds of societies, including the individualistic society that Mill himself glorified. There is never much that individuals can do to break out of the established framework of things and see the world from their own, independent, perspective. All our faculties are too thoroughly conditioned by the society in which we live. Occasionally, there will no doubt be people who live up to Mill's ideals, but they will never be that many and society in general will regard them as subversives, as fools, or as both. Most of us are too timid, too conformist, and simply not creative enough.

In fact, Mill himself is a good illustration of these shortcomings. A highly intelligent and original thinker, he was nevertheless unmistakably a product of his own environment. ${ }^{7}$ While his defence of female suffrage may strike us as ahead of his time, his defence of British imperialism, or his fear of the lower classes, were perfectly Victorian (Cf. Mill, 1869/1991: 469-582; Mill, 1861/ 1991: 335-36). Mill too was a conformist, and if that can be said about him, there is surely little hope for us lesser mortals. If it only were up to individuals, in other words, not much reflection or critical thought would take place.

To illustrate this point, consider the difference between Western liberal societies and the societies of the old-style Communist block. There is no doubt

\footnotetext{
${ }^{7}$ More examples are available in his autobiography. See Mill, 1873/1944.
} 
that the former set of societies was vastly more reflective than the latter, and this was also an important reason for the success of the West and the failure of Communism. By constantly reflecting on themselves, Western societies became more flexible and better prepared to meet whatever challenges that would be thrown at them. If Westerners think this success is down to their own individual achievements, however, they are wrong. The West was never reflective because it contained particularly reflective individuals - on average it did, and does, not! On the contrary, it is striking how much prejudice, narrowmindedness and sheer stupidity that still survive even in the most advanced of modern societies. The citizens of the former Soviet Union were, as individuals, often far better educated and not necessarily less reflective.

What made all the difference, however, were the kinds of institutions that Western societies contained, and, by implication, the kinds of institutions that the Communist block lacked. Instead of reflective individuals being, the secret to West's success was, and is, a unique set of reflective institutions (Cf. North, 1990; North \& Thomas, 1973; Hamilton, 1938). Or rather, in the West institutions were put in place that allowed even fairly mediocre individuals to reflect creatively and efficiently together. As long as the institutions in question are well designed, the quality of the output has little to do with the quality of the individuals involved. Institutional brilliance does not require brilliant individuals. In fact, the institutions soon become far more intelligent than any of the people they comprised.
More concretely put, institutions facilitate reflection in a large number of different ways. Institutions make it possible for people of different backgrounds to meet in order to exchange information and points of view; institutions provide the means of gathering, combining and comparing perspectives. Institutions supply the infrastructure, the material, the funding, the archives, the laboratories, the jargon, the ways of judging contributions. And perhaps most importantly: institutions allow for vast increases in the intellectual division of labour. Just as modern factories, reflective institutions make it possible for tasks to be ever more narrowly defined and performed by ever more skilled people. As a result, the production of knowledge expands rapidly although no individual has a grasp of more than a portion of the process.

\section{the West: the discovery of distance}

Modern, Western, societies are highly reflective, and the reason is a particular combination of technological and institutional factors. In order to understand the origin of this fortuitous combination, it is necessary to turn to history.

The European Middle Ages have often been talked about as a period of 'darkness,' and what people have in mind who use this epithet is precisely the purported lack of reflective capability (Mommsen, 1942:226-42; Nauert, 1995: 19-23). The Church imposed a homogenous set of beliefs and a uniform ritual on all Europeans. The teachings of the Church were totalitarian in the strict sense that a few canonical texts mainly the Bible and writings by the 
Church fathers - provided a total explanation of everything everywhere. The medieval world was closed, geographically and conceptually; everything was known and accounted for. The world has never been as well understood as it was in Europe in the $13^{\text {th }}$ century.

Yet such a negative assessment is surely unfair.The medieval era was never as dark or as dogmatic as later, more "enlightened,' generations have portrayed it. For one thing, the conceptual system imposed by the Church was never free of internal contradictions. There were in fact plenty of loose ends and ideas that failed to go smoothly together. Throughout the Middle Ages, endless intellectual debates sought to iron out these inconsistencies. What, for example, is the relationship between reason and faith? How do universal categories relate to individual objects? And if God really is all-powerful, why did he not create more things than there are? (Lovejoy, 1936: 67-98). In this way, medieval, so-called 'Scholastic,' philosophy became a procedure with the help of which the world could be reflected on (Cf. Durkheim, 1893/1984: 114-15). Scholasticism was a means of establishing external, philosophically derived, points of view from which the empirical world could be better observed.Scholasticism provided an institutionalised procedure for reflection.

Having said this, however, there were obvious limits to how much that could be seen from these medieval perspectives. There was, for example, no place for physical experiments or for philological and historical analyses; in fact, there was little place for empirical in- vestigations of any kind (Rüegg, 1996: 16-17). Similarly, although religious language could be used to voice criticism, the religious truths that this language presupposed could themselves not be questioned. In this way, even critical thought came to affirm the validity of the officially sanctioned worldview (Cf. Cohn, 1970: 197). Most generally put, the problem of the European Middle Ages was a lack of distance. The medieval world was a fishbowl world, a closed conceptual universe, and there was no proper outside from which man and society could be viewed.

This situation changed in the $15^{\text {th }}$ century as the medieval fishbowl first began to crack and eventually was completely shattered. Often this development is referred to as 'the Renaissance,' and while it comprised a large number of separate processes and events, a crucial part of the Renaissance was a revolution in reflective capability. There are at least three key components to this reflective revolution. First of all, the discovery of worlds outside of the medieval fishbowl; secondly, the development of new technologies of reflection; and finally, the emergence of new reflective institutions.

As far as discoveries were concerned, three new worlds were chanced upon (Boorstin, 1983). The first was the world of classical Greece and Rome; the second, a number of previously unknown continents beyond the sea; the third, the endless universe of the postCopernican cosmology. As a result of these discoveries, enormous distances suddenly opened up, together with a wealth of new points of view. Placing themselves in classical Athens, in the 
Americas, or at a randomly given point in limitless space, the discoverers were in a position to view Europe, its habits and inhabitants, in entirely different ways. For the first time, the Europeans were able to see themselves from the outside. What they saw was often both surprising and strange.

The view from Antiquity allowed the Europeans to see themselves as the heirs of a society that not only was highly sophisticated, but also completely nonChristian. Reviving this ancient culture became the preoccupation of a new generation of scholars who inspired radically new departures in fields ranging from philosophy and literature to the arts (Nuaert, 1995). The view from the Americas, helped the Europeans question many of their received opinions regarding what it meant to be a human being and how society should be organised. A new genre of utopian literature, inspired by the geographical discoveries, made fun of the received opinions and pointed to alternative ways of organising social life. The view from space, finally, provided the Europeans with a far more realistic conception of man's place in the universe. As some speculated, the universe might be infinite, and there might be an infinite number of planets inhabited by an infinite number of unknown beings.

Perhaps it is possible to say that the view from Antiquity provided a historical perspective on man; the view from the Americas, a social perspective; and the view from space, a natural perspective. While in the Middle Ages, the all-dominant perspective on man had been religious, the modern perspectives are his- torical, social and natural. On their own, each account can be at least as pretentious and totalising as ever the medieval explanation, and there will always be those who refuse to see man as anything but a historical, social or natural being. In contrast to the Middle Ages, however, none of these accounts has been able to attain supremacy over the others. The three images cannot be reduced to one another, neither can they easily be combined.

\section{The West: Technologies and Institutions}

None of these discoveries would have amounted to much, however, but for a number of technological and institutional changes taking place in Europe from the $15^{\text {th }}$ century onwards. New technologies and institutions perpetuated the accomplishments of the first generations of discoverers, made them permanent, and easy to build on by others.

The most striking example here is the printing press (Eisenstein, 1982; Eisenstein, 1993). Thanks to print, people could communicate over large distances, reading and cross-referencing each other much more extensively than ever before. As more books began circulating around Europe, so did the ideas they contained. Suddenly people had access to more information, and more, and more alternative, points of view. Instead of reflecting alone, people could reflect together and thus more efficiently than any individual would have done by him or herself. In this way, the printing press allowed new forms of collective intelligence to emerge. 
When new authorities became available, the power of the old ones was inevitably reduced; people began criticising the world they saw around them with the help of standards they only had read about in books. Suddenly, questions of right and wrong became divorced from a particular way of life. As a result it soon became impossible to maintain a unified Christian canon, and even impossible to maintain a unified Christian church (Eisenstein, 1983: 148-86). Martin Luther's translations of the Bible into German and his Small Catechism, 1529, were among the first best-sellers of the modern age. And the Reformation of the $16^{\text {th }}$ century was a revolution brought about by readers who had established their own connection to God, not mediated through the sacraments of the Church but instead through print.

At the same time, reflective activities became far more thoroughly institutionalised than ever before. In the early modern era, a large number of institutions emerged that in one way of another were required to engage in reflection, and many reflective institutions that survived from the Middle Ages received new mandates. Reflection was the responsibility of, inter alia, public bureaucracies, courts of law and religious sects, but also, for example, banks and stock markets. Three institutions were, however, particularly important in this respect: universities, scientific academies and parliaments.

Consider, first, the contribution of universities (R?egg, 1996; Haskins, 1927/ 1993: 368-97). European universities are medieval institutions dating back to the $12^{\text {th }}$ century. As such, they were responsible mainly for the education of theologians and lawyers and were originally dominated by Scholastic philosophy. In the new Humanist universities that began appearing in the $16^{\text {th }}$ century, however, the logical exercises of medieval philosophy were replaced by a number of practices that emphasised reflective thought. One such was the critical method of analysing historical source material. Another practice was a training in rhetoric (Nauert, 1995: 2079). In mock debates, students learnt to argue points pro as well as contra, and in this way learn how to simultaneously see an issue from many different points of view.

Although none of the great intellectual movements of the last five hundred years originated in the university, they all sooner or later came to influence the university curriculum. The Reformation and Counter-Reformation, the Scientific Revolution and the Enlightenment, the Industrial and the Computer Revolutions, all had an impact on society primarily through their impact on the university. People learnt about the latest intellectual achievements as they passed through the universities in their most formative years. Above all, however, the university was the place where they encountered the Humanists' curriculum and its pedagogy of critical thought. To the extent that this curriculum has survived - and it has to a surprising extent - this critical tradition is still alive in universities today.

Reflection was also the main activity of the new scientific academies that began appearing throughout Europe in the course of the $17^{\text {th }}$ century (Boorstin, 1983: 386-417; Hartley, 1991; Bacon, 1627/1989). As a setting for reflection, 
the uniqueness of the academy rested and still rests - in its mode of organisation. Here the search for new knowledge was divided between researchers according to an intricate division of labour (Polanyi, 1962/1969; 4972; Mumford, 1970: 114-5). Concentrating on ever more minute tasks, each scientist became ever more knowledgeable about a particular topic. Instead of making researchers increasingly irrelevant to each other, however, the academy offered an framework through which information could be shared. The academy allowed researchers to specialise, but only in order to co-operate much more efficiently. Across Europe, academies financed exhibitions, expeditions and excavations; they kept in contact with foreign and domestic correspondents, organised public lectures and debates, and gathered specimens and artefacts in their museums and books in their libraries. Discoveries were published in reports - the first scholarly journals — which were widely disseminated and consulted. From this time onward, scientific progress became an institutional rather than an individual achievement.

A third reflective institution to emerge in Europe was the parliament. Parliaments, just like universities, have medieval origins. Initially they were conceived of as means by which the kings could gather taxes, but also information, from their subjects (Davies \& Denton, 1981: 5-6, 19-24; Bagehot, 1867/1997: $74,151-2)$. In return for these contributions, however, the people's representatives began demanding privileges such as a measure of control over state finances. Medieval parliaments met only rarely - perhaps once every few years
- and the debates were clearly stagemanaged by the kings. Yet the fact that a forum was established where public deliberations could take place was itself significant. As long as the parliament met, the king had to give reasons for his actions and persuade rather than force people to follow him. Parliaments established the first outline of what later would come to be referred to as a 'public sphere.'

In the early modern period, parliaments disappeared in some countries, while their position was strengthened in others (Finer, 1999: 1307-74; Ertman, 1997). In so called 'absolutist' states such as France, Prussia, Austria and Russia, the rulers found independent sources of income and no longer needed to rely on parliaments to give their consent to new taxes. In other countries England, Sweden, Poland and Hungary - the kings were never as fortunate, but the result was beneficial to society as a whole. Here representatives of the people would continue to meet in order to discuss issues of common concern. That is, parliaments were not only places where decisions were made, but also where issues were reflected on (Bessette, 1994: 6-39). By providing the representatives of the people with institutional procedures for talking together, decisions of higher quality could be reached than where an individual such as an absolutist monarch - made decisions alone.

From around the year 1500, technologies such as the printing press and institutions such as universities, academies and parliaments, made Europe vastly more reflective than it previously had been, and more reflective, also, than oth- 
ers parts of the world. Together these technologies and institutions connected to constitute a form of social mechanisms through which reflection could be carried out. With the help of these reflective machines, different perspectives were systematically gathered, combined and compared. As a result of their operations, new things were no longer discovered by chance, but by design; reflection was no longer left to creative individuals, but was instead the responsibility of institutionalised procedures.

\section{East Asia}

The question is how East Asia compares with Europe in these respects. To what extent do East Asian societies provide scope for reflection? And how is reflection carried out? Which is the role, if any, of different technologies and institutions? Again it is enlightening to look at these questions from a historical perspective.

It was obvious to John Stuart Mill, as it has been to most Europeans, that East Asia was to be judged in terms of the successful development of the West. The West was the model, and East Asia was the epigone. Once the comparison is set up in these terms, however, East Asia will necessarily come out as inferior (Hamilton, 1985: 65-89). Consider, for example, the printing press. While the idea of moveable types indeed was a Chinese invention, not a Western, its use was quite different in a language written with thousands of ideograms. Above all, however, the printing press was never used for a public process of reflection; there was no 'public opinion' and no 'public sphere.' In fact, there was no free press in East Asia until the $20^{\text {th }}$ century, and even then its role, and its freedom, were usually quite circumscribed.

As Mill and all Westerners have been quick to point out, East Asia was also sadly deficient in Western-style institutions. There were no universities and hence few institutionalised procedures for training the young, for exchanging information and for disseminating ideas. ${ }^{8}$ And even when universities were put in place - Tokyo University was founded in 1877, and Chulalongkorn University in 1899 - they adopted only the formal aspects of the Western curriculum, not its Humanist pedagogy and hence not its reflective core. Scientific academies were also missing, and although for example Chinese science was highly sophisticated, new advances were more difficult to publicise and thus more difficult to build on by others.

Parliaments too were lacking in traditional East Asian society, and for this reason there was no arena where public deliberation was institutionalised. As a result, East Asian rulers never had to explain themselves to the subjects they

\footnotetext{
${ }^{8}$ This verdict will of course depend on how universities are distinguished from other educational institutions. Note also that there were universities in India, such as that in Takshash?1?, founded 700 B.C. which attracted not only Indian students, but also students from as far as Babylonia, Greece, Syria, Arabia and China.
} 
were ruling. Throughout the region, political power was eerily silent.And even when parliaments finally were put in place in the $20^{\text {th }}$ century, they had few of the characteristics of their European counter-parts. More than anything, East Asian parliaments were, and are, mechanisms for the distribution of patronage, but otherwise they are quite irrelevant to the real exercise of power. Today, East Asia may be democratising, but as a number of scholars have pointed out, democracy does not necessarily entail Western-style liberalism (Bell et al, 1995)

To keep a score-card of this kind is, however, quite unfair. There is no reason why East Asia should have developed in accordance with a Western model, and to fault it for not doing so is foolish. The question is rather whether there were any functionally equivalent forms of reflection indigenous to East Asia. Whether East Asian societies did what Europeans did, but only in a different manner. The answer to this question is clearly yes.

A first striking fact is the visual character of much of traditional East Asian cultures (Clunas, 1997). A society that attaches great importance to the visual will always be inherently reflective. The asthetics of Japanese traditional arts from ikebana to kendo - is, for example, to a high degree based on the appreciation of the visual impact of space. In China, there is a long tradition of pictorial art, and societies influenced by Chinese culture are the only ones outside of Europe where landscape paintings are presented as a genre onto itself (Cahill, 1982; Clark, 1976: 1-32).
No work of art can be produced which does not, at least to some extent, reveal the preconditions of the society in which it was painted. The logic here is the same as that of a mirror. In its pictorial art, a society projects itself onto an external reality, thus making itself available to itself. The sophisticated tradition of artistic connoisseurship developed in East Asia meant that people really spent time reflecting on these imagines of themselves.

A second striking fact is the collective rather than the individual character of this reflective enterprise. In Japan, nature is often appreciated in groups. People gather to look at the cherry or plum blossom in the spring, the full moon in August, or the snow on a mountain in the winter.' Similarly, in China, works of art were usually appreciated in groups rather than by individuals alone (Clunas, 1997: 57-76).

A related observation concerns the canonical nature of the themes portrayed. At first blush, Chinese ink paintings all look the same. Everywhere we see identical-seeming water buffaloes and monkeys, lonely fishermen and mountains. In fact, written East Asian sources often appear equally monotonous. Throughout the region, the same themes drawn form Buddhist and Confucian scriptures were constantly reiterated, and the gallery of folk-heroes was equally fixed and equally well-known. Similarly, all Japanese haikus seem to be about leaping frogs, dew drops and falling cherry blossoms.

\footnotetext{
9 Compare, for example, hanami, cherry blossom viewing; yukimi, snow scene viewing; tsukimi, a moon-watching party.
} 
This elaborate canon is, no doubt, is the 'despotism of custom' to which John Stuart Mill referred. What Mill failed to appreciate, however, was the creative potential of a canonical tradition whether it be within literature, religion or the arts. By reflecting on the same themes, people are able to participate in a common collaborative enterprise. As a result, they share a common code through which argument, cogently and coherently, can be communicated. And even when people break with the shared tradition - as many East Asian painters and religious eccentrics were wont to do - it was immediately obvious to everybody in what their particular contributions consisted (Cahill, 1982:184225; Ketelaar, 1990). Before long, these new departures, no matter how radical, would be incorporated into the canon, built on by others, and reflected in new thought.

In addition, the two dominant philosophical systems of East Asia - Buddhism and Confucianism - provided ways in which reflection could be institutionalised. Both systems of thought presented fully coherent descriptions of alternative worlds. In the case of Confucianism, the description is given mainly in terms of moral standards; in the case of Buddhism, mainly in terms of a metaphysic. By exploring the logic of these alternative realities, people would start inhabiting them and gradually come to see contemporary society from the perspectives they afforded. This allowed new insights to be gained. Far from passively accepting the existing order of things, Buddhist monks and Confucian scholars would often become social, cultural and political critics. Or rather, the potential for both affirmation and critique were built into the same system of thought. The Buddhist prohibition against the taking of life could, for example, have farreaching political consequences. The same is true for the Confucian ideal of the virtuous bureaucrat and scholar.

Through the Chinese examinations system, and through the rigorous training of the Buddhist mystic, this critical potential was institutionalised in a given set of procedures. In the case of Thailand, where a large proportion of young men went through a period of religious training, the monasteries played an important role in teaching successive generations how to think reflectively. ${ }^{10}$ In this way, the Chinese bureaucracy and Buddhist monasteries became, in some respects at least, functional counterparts to European universities.

Much of this description may recall the European Middle Ages. In both places, reflection was a collective enterprise, organised around a few canonical themes, and institutionalised by a religious establishment. In addition, East Asia had access to many of the same technologies of reflection as people in the West. Just as Europe, East Asia had access to writing, and in both parts of the world writing allowed people to externalise their thoughts and preserve them for posterity. What in both cases was reflected on was a written tradition that was far larger, and more exactly rendered, than the oral traditions of many other parts of the world.

\footnotetext{
Although, as a result of industrialisation and the concomittant pressures of education and jobs, the tradition of becoming a monk for three months no longer is the norm
} 
To compare traditional East Asian society with that of the European Middle Ages is not an indictment, however. The Middle Ages have been described as 'dark' by people who describe themselves as 'enlightened,' yet the Middle Ages could just as well - in fact more fairly - be described as establishing the preconditions for all developments that later occurred in the West. The transition from the Middle Ages to modernity is thus not the case of 'enlightenment' replacing 'superstition,' but instead simply the case of one society preparing the way for another. The same argument applies to East Asia. Just as in Europe, traditional East Asian society established the preconditions for what in the $19^{\text {th }}$ and $20^{\text {th }}$ centuries was to become a rapid process of modernisation.

At the same time, East Asia never experienced the European discovery of distance. The Chinese were active geographical explorers, travelling as far as to the southern-most tip of Africa, but in 1433,1449 and 1452 , imperial edicts imposed increasingly severe punishments on Chinese subjects going abroad (Boorstin, 1983: 186-201) The Japanese authorities drew similar conclusions. In 1639 , all foreigners were thrown out of the country, Japanese subjects banned from foreign travel, and all ocean-going ships destroyed. Japan was to remain closed to the outside world for the next 229 years. Geographically speaking, East Asia was never able to see itself from the outside.

As far as historical and cosmological distance was concerned, the Chinese never experienced any European-style breakthroughs mainly since their historical and cosmological perspectives al- ways were considerably broader. There was never, for example, a Europeanstyle 'Renaissance' of a half-forgotten historical past. China was of course, just as Rome, overrun by foreign 'barbarians,' but in contrast to the Roman case, this never meant the end of civilisation. In China, there was, even in times of revolutionary upheaval, a strong sense of the presence of the past. There was simply nothing to revive.

As far as cosmological distance was concerned, East Asian cultures were always more accommodating (Needham, 1985, 2: 67-221; Allan, 1991). Rival scientific hypotheses were always allowed to co-exist. For this reason, a considerable amount of geographical, historical and cosmological distance could always be found within East Asia itself.

Compared to the European Middle Ages, East Asia was always vastly more pluralistic. In Europe, Christianity coexisted with Judaism only by means of the strictest separation, and when Christianity came into contact with Islam, the result was usually war. In Europe, there was only one language of learning, one religion, and one religious establishment. In addition, the Christian god was extremely demanding. He was the only god, and no other gods were allowed but him. In order to make sure that people really believed, the Church required them to confess their sins on a weekly basis. What mattered more than anything was the state of each person's mind, and in the confession this state was regularly inspected by the religious authorities. There is hardly any doubt that this mind-control stifled creativity. 
Once again John Stuart Mill was wrong. What he had seen in East Asia was a homogeneity that he compared negatively with the pluralism of European cultures (Mill, 1859/1985: 138). Pace Mill, however, East Asia was where there were many gods, and many independent religious systems that competed with one another. What is remarkable to a Westerner is the fact that these systems could co-exist without obvious and prolonged confrontation, but also without merging into each other and losing their identity. In East Asia, the gods were not jealous and religions added to, rather than subtracted from, each other (Cf. Koh, 1996: 191-201). Equally importantly, East Asian gods never tried to control people's minds, but were instead content to control their bodies. The emphasis was not on orthodoxy, the right belief, but instead on orthopraxy, the right ritual, such as, for example, the funeral rites prescribed according to Confucianism (Watson, 1993: 80-103).

All these factors helped make traditional East Asian societies reflective. Conflicting systems of thought co-existed in the same culture, and often in the same mind. As a result, distance - and alternative points of view - were built into the very fabric of social life. The emphasis on orthopraxy meant that people could believe and think whatever they liked as long as they were prepared to go through the required motions.

\section{conclusion}

The aim of this article was to rebut a claim most forcefully made by John Stuart Mill, but present in a stereotypical form in Western minds until this day.
Western progress, the argument goes, is the result of critical faculties exercised by individual minds. East Asia, by contrast, is conformist, collectivist, and for that reason unable to change as quickly or as flexibly.

There are two main flaws in this argument. Individuals, first of all, matter far less for the quality of critical thinking than Westerners typically imagine. On the contrary, the critical capability of society is largely dependent on access to different technologies of reflection and on the extent to which reflection is institutionalised. All reflection may happen in individual minds, but individual minds will produce few results unless they are given access to a certain technology and unless they are connected with each other through institutional procedures. The actual historical development of the West supports this view rather than Mill's individualism.

Given this conclusion, the second flaw in the argument is easily spotted. East Asia's 'collectivism' and 'conformism' are not examples of the 'despotism of custom' as much as ways of institutionalising reflection. Reflection is by nature a collective activity and it can very well be canonical in form as long as the canon in question is discussed in a creative and undogmatic fashion. This was precisely the case in East Asia. The co-existence of faiths and the focus on ritual made East Asian societies pluralistic and provided people with the freedom they needed to explore the potentialities of social life.

To end on a slightly more speculative note, it is perhaps possible to say that the reflective capacity of traditional East 
Asian societies helps explain two intractable puzzles of historical sociology. Why, first of all, was it that China, Japan and Thailand managed to preserve their independence in the $19^{\text {th }}$ century even as most of the non-European world was reduced to the status of colonies? Secondly, why was it that a number of East Asian countries, again almost uniquely outside of Europe, managed to successfully modernise in the $20^{\text {th }}$ century? The answer to both questions is complex, but an important factor was the reflective capability of East Asian societies. In the $19^{\text {th }}$ century, East Asian elites - Japanese and Thai in particular - were able to analyse the new and rapidly changing environment and to react to it resolutely and pre-emptively. A reflective capability, that is, was crucial for modernisation. Similarly, after the end of World War II, East Asian countries were quick to take advantage of the new geopolitical situation and to adjust their economies to world-wide changes in consumer demand. Again, the situation was quickly analysed by East Asian leaders and their actions were resolute and pre-emptive.

It is often said that East Asian societies must become better at 'critical thinking,' if not for the sake of the personal development of their inhabitants, at least for the sake of the economic development of the countries concerned. What usually is meant by such statements is that East Asia should emulate the West and somehow encourage individuals to think more freely and creatively. However, while individual freedom and creativity surely are good things, they are difficult to accomplish under the best of circumstances. To emulate the West would be a mistake since individual Westerners are far less original than they think they are. And in any case, individuality had little to do with how critical thinking emerged in the West. Instead, the question is surely how new and better technologies of reflection can be developed and how institutions responsible for critical thought can be further improved. In this respect, East Asia has indigenous traditions that are at least as important as any foreign examples.

\section{References}

Allan, Sarah. The Shape of the Turtle: Myth, Art, and Cos mos in Early China (Albany: State University of New York, 1991)

Arendt, Hannah. Life of the Mind: Volume I, Thinking (San Diego: Harcourt, Brace,Janovitch, 1977)

Asia Week, 'Best Universities, 1999,' available athttp://www. asiaweek.com/asiaweek/ universities/scitech/3.html.

Asian Development Bank, 'Thai land,' in the Asian Develop ment Outlook, 2000 (Manila: Asian Development Bank, 2000) pp. 116-17, available at http://www.adb.org/docu ments/books/ado/2000/ thailand.pdf.

Baba, Yasunori \& Ken-ichi Imai, 'Systematic Innovation and Cross-Border Networks: the Case of the Evolution of the VCR Systems,' in Entrepre neurship, Technological In novation and Economic Growth: Studies in the Schumpeterian Tradition, edited by Frederic M. Scherer \& Mark Perlman (Ann Ar 
bor: University of Michigan Press, 1992)

Bacon, Francis. [1627], The New Atlantis and The Great Instauration (Wheeling: Crofts Classics, 1989)

Bagehot, Walter . [1867], The En glish Constitution (Brighton: Sussex Academic Press, 1997)

Bell, David A., David Brown, Kanishka Jayasuriya and D.M. Jones, Towards Illib eral Democracy in Pacific Asia (London: St. Martin's, 1995)

Bessette, Joseph M. The Mild Voice of Reason: Deliberative De mocracy \& American Na tional Government (Chicago: University of Chicago Press, 1994)

Boorstin, Daniel J. The Discoverers: A History of Man's Search to Know His World and Himself (New York: Vintage Books, 1983)

Cahill, James. The Compelling Im age: Nature and Style in Sev enteenth-Centrury Chinese Painting (Cambridge: Harvard University Press, 1982)

Clark, Kenneth. Landscape into Art (London: John Murray, 1976)

Clunas, Craig. Pictures and Visuality in Early Modern China (Lon don: Reaktion Books, 1997)

Cohn, Norman. The Pursuit of the Millennium: Revolutionary Millenarians and Mystical Anarchists of the Middle Ages (London: Pimlico, 1970)

Davies, R. G. \& J. H. Denton (eds.) The English Parliament in the Middle Ages (Manches ter: Manchester University Press, 1981)

Dictionnaire historique de la langue française, 'Critique,' and

'Crise' (Paris: Robert, 1993)

Durkheim, Émile [1893], The Divi sion of Labour in Society, translated by W. D. Halls (New York: Free Press, 1984)

Eisenstein, Elizabeth L. The Print ing Press as an Agent of Change (Cambridge: Cam bridge University Press, 1982)

Eisenstein, Elizabeth L. The Print ing Revolution in Early Mod ern Europe (Cambridge: Cambridge University Press, 1983)

Ertman, Thomas. Birth of the Levia than: Building States and Regimes in Medieval and Early Modern Europe (Cam bridge: Cambridge University Press, 1997)

Finer, S. E. 'The Two Traditions: Absolute versus Parliamen tary Democracy,' in his The History of Government: III, Empires, Monarchies and the Modern State (Oxford: Ox ford University Press, 1999)

Goody, Jack \& Ian Watt, 'The Con sequences of Literacy,' Com parative Studies in History and Society, vol. 5, 1963.

Goody, Jack The Logic of Writing and the Organization of So ciety (Cambridge: Cam bridge University Press, 1986)

Gregory, Richard. Mirrors in Mind (Harmondsworth: Penguin, 1998)

Halberstam, Michael. Totalitarian ism and the Modern Concep tion of Politics (New Haven: Yale University Press, 2000)

Hamilton, Gary G. 'Why No Capi talism in China?: Negative Questions in Historical Com parative Research,' in Max Weber in Asian Studies, edited by Andreas E. Buss 
(Leiden: E.J. Brill, 1985)

Hamilton, Walton H. 'Institution,' International Encyclopedia of the Social Sciences, 1938.

Hartley, Harold. The Royal Society: Its Origins and Founders (London: Royal Society,1991)

Haskins, Charles Homer . [1927], The Renaissance of the Twelfth Century (Cambridge: Harvard University Press, 1993)

Hofstede, Geert. Culture's Conse quences: International Dif ferences in Work-Related Val ues (Newbury Park: Sage, 1980)

James, William. [1902], The Variet ies of Religious Experience (Harmondsworth: Penguin, 1985)

Ketelaar, James Edward. Of Heretics and Martyrs in Meiji Japan: Buddhism and Its Persecu tion (Princeton: Princeton University Press, 1990)

Koh, Byong-ik, 'Confucianism in Contemporary Korea,' in Tu Wei-ming, (ed). Confucian Traditions in East Asian Mo dernity: Moral Education and Economic Culture in $\mathrm{Ja}$ pan and the Four Mini-Drag ons_(Cambridge: Harvard University Press, 1996)

Koselleck, Reinhart. [1959], Cri tique and Crisis: Enlighten ment and the Pathogenesis of Modern Society (Oxford: Berg, 1988)

Lovejoy, Arthur O. The Great Chain of Being: A Study of the His tory of an Idea (Cambridge: Harvard University Press, 1936)

Maruyama, Maguroh. 'Alternative Conceptions of Manage ment: Insights from Asia and Africa,' in Exploring Man agement across the World: Selected readings, edited by David Hickson
(Harmondsworth: Penguin, 1997)

McLuhan, Marshall. [1964], Under standing Media: The Exten sions of Man (Cambridge: MIT Press, 1998). pp. 7-21.

Mill, John Stuart. [1859], On Liberty (Harmondsworth: Penguin, 1985)

Mill, John Stuart. [1861], 'On Rep resentative Government,' in John Stuart Mill, On Liberty and Other Essays (Oxford: Oxford University Press, 1991)

Mill, John Stuart. [1869], 'The Subjection of Women,' in John Stuart Mill, On Liberty and Other Essays (Oxford: Ox ford University Press, 1991)

Mill, John Stuart. [1873] Autobiog raphy of John Stuart Mill (New York: Columbia University Press, 1944)

Miller, Jonathan. On Reflection, (London: National Gallery Publications, 1998)

Mommsen, Theodor E. 'Petrarch's Conception of the "Dark Ages",' Speculum, vol. 17, 1942. pp. 226-42.

Mumford, Lewis. The Pentagon of Power: The Myth of the Ma chine, volume 2 (New York: Harcourt, Brace, Jovanovich, 1970)

Nauert, Charles G. Humanism and the Culture of Renaissance Europe (Cambridge: Cam bridge University Press, 1995)

Needham, Joseph. The Shorter Sci ence \& Civilisation in China: Volume 1, abridged by Colin A. Ronan (Cambridge: Cam bridge University Press, 1978)

North, Douglass C. \& Robert Paul Thomas, The Rise of the 
Western_World: A New Eco nomic History (Cambridge: Cambridge University Press, 1973)

North, Douglass C. Institutions, In stitutional Change and Eco nomic Performance (Cam bridge: Cambridge Univer sity Press, 1990)

Polanyi, Michael. [1962], 'The Re public of Science: Its Politi cal and Economic Theory,' in his Knowing and Being (Chi cago: University of Chicago Press, 1969)

Rüegg, Walter. 'Themes,' in A His tory of the University in Eu rope: Volume I, Universities in the Middle Ages, edited by Hilde de Ridder-Symoens (Cambridge: Cambridge University Press, 1996)
Watson, James L. 'Rites or Beliefs?: The Construction of a United Culture in Late Imperial China,' in China's Quest for National Identity, edited by Lowell Dittmer \& Samuel S. Kim (Ithaca: Cornell Univer sity Press, 1993) pp. 80-103.

Wei-ming, Tu. (ed). Confucian Tra ditions in East Asian Modernity: Moral Education and Economic Culture in Japan and the Four Mini-Dragons (Cambridge: Harvard Uni versity Press, 1996)

World Bank, 'Making the Most of the Knowledge Economy,' in East Asia: Recovery and Beyond (Washington: World Bank, 2000) pp. 61-64, avail able at http:// www.worldbank.org/html/ extpb/earecovery.htm. 